\title{
THE INFLUENCE OF JOB SATISFACTION AND LEADERSHIP STYLE ON ORGANIZATIONAL CITIZENSHIP BEHAVIOR (STUDY AT PT IDE JAYA KREASINDO)
}

\author{
Bagus Tri Pratikto \\ Faculty of Economic State University of Jakarta \\ Email: Bagustripratikto@yahoo.com \\ I Ketut R Sudiarditha \\ Faculty of Economic State University of Jakarta \\ Email: Sudiardhita@yahoo.com \\ Sholikhah \\ Faculty of Economic State University of Jakarta \\ Email: sholikhah@unj.ac.id
}

\begin{abstract}
The purpose of this study is : 1) To know the description of job satisfaction and the leadership style on Organizational Citizenship Behavior (Study at PT Ide Jaya Kreasindo) 2) To know the effect of job satisfaction on Organizational Citizenship Behavior 3) To know the effect of the leadership style on Organizational Citizenship Behavior 4) To know the effect of job satisfaction and the leadership style on Organizational Citizenship Behavior simultaneously. Research methods using simple random sampling. Sampling technique using simple random sampling technique and of questionnaires of 77 observations from PT Ide Jaya Kreasindo's employees using SPSS 16.0.The empirical result shows that job satisfaction and the leadership style has positive and significant effect on organizational citizenship behavior. Simultaneously test shows that job satisfaction and the leadership style effects organizational citizenship behavior.
\end{abstract}

Keywords: Job Satisfaction, The Leadership Style, Organizational Citizenship Behavior 


\section{PENDAHULUAN}

Organisasi mengharapkan kinerja individual yang semaksimal mungkin untuk dapat mencapai keunggulan perusahaan, karena pada dasarnya kinerja individual atau kelompok kerja pada akhirnya mempengaruhi kemajuan perusahaan secara keseluruhan. Kriteria kinerja yang baik menuntut karyawan untuk berperilaku sesuai harapan organisasi atau perusahaan. Menurut Soegandhi dkk (2013), "perilaku ini tidak hanya mencakup in-role yaitu bekerja sesuai dengan standar job description saja namun juga extra-role yaitu memberikan kinerja lebih dari pada yang diharapkan perusahaan. Perilaku ini cenderung melihat karyawan sebagai makhluk sosial yang memiliki kemampuan untuk berempati kepada orang lain dan lingkungannya serta menyelaraskan nilai-nilai yang dimiliki dengan nilainilai lingkungan sekitarnya”.

Perilaku yang dapat meningkatkan produktivitas karyawan di dalam perusahaan tersebut adalah perilaku extra-role atau disebut juga sebagai perilaku kewarganegaraan dalam organisasi (Organizational Citizenship Behavior). Bogler dan Somech (dalam Ristiani, 2013) mengingatkan bahwa "peningkatan efektifitas, efisiensi, dan kreatifitas tersebut sangat bergantung pada kesediaan para karyawan untuk berkontribusi secara positif dalam menyikapi perubahan”.

PT. Ide Jaya Kreasindo merupakan salah satu perusahaan yang bergerak di bidang event organizer (EO), dimana EO tersebut memiliki tugas membantu klien (client) untuk menyelenggarakan acara yang diinginkan, seperti launching product, company gathering, anniversary, exhibitions, seminar, promosi, talkshow, dan sebagainya, dari tahap persiapan hingga sampai dengan pelaksanaan event agar berjalan dengan baik dan lancar. Untuk mencapai tujuan tersebut, tidak hanya terlepas dari kinerja karyawannya, namun didukung pula oleh individuindividu di dalam perusahaan yang mampu memberikan kontribusi positif dan menguntungkan bagi perusahaan. Kontribusi ini dapat berupa sikap OCB yang dilakukan oleh karyawan untuk perusahaan seperti melakukan hal-hal di luar tugas pokok yang dapat memberikan keuntungan untuk perusahaan.

Sebagai suatu bentuk perilaku karyawan yang cukup komprehensif dan memiliki arti penting dalam mencapai keunggulan kinerja sebuah organisasi, OCB 
memiliki beberapa bentuk perilaku, antara lain kesanggupan untuk melampaui standar minimum yang telah ditetapkan (conscientiousness). Bahkan, jika OCB dianggap sebagai extra-role behavior, maka seorang karyawan seharusnya tidak hanya sekedar memenuhi kewajiban formalnya saja, tetapi juga harus mampu berperan secara sosial dan struktural melebihi harapan organisasinya terkait standar kinerjanya tersebut. Adapun salah satu data yang bisa digunakan untuk mewakili karakteristik OCB dari suatu perusahaan adalah absensi karyawan dan jumlah karyawan yang keluar (resign)

Tabel 1. Data Absensi Karyawan PT Ide Jaya Kreasindo

\begin{tabular}{cccc}
\hline Bulan & Kehadiran & Tepat Waktu & Ketidakhadiran \\
\hline April & $87 \%$ & $83 \%$ & $13 \%$ \\
\hline Mei & $90 \%$ & $80 \%$ & $10 \%$ \\
\hline Juni & $86 \%$ & $78 \%$ & $14 \%$ \\
\hline Juli & $85 \%$ & $75 \%$ & $15 \%$ \\
\hline Agustus & $85 \%$ & $80 \%$ & $15 \%$ \\
\hline
\end{tabular}

Sumber: HR Division PT Ide Jaya Kreasindo (2014)

Tabel 1 di atas menjelaskan bahwa tingkat kehadiran para karyawan PT. Ide Jaya Kreasindo sudah cukup baik. Akan tetapi tingkat kehadiran tepat waktu para karyawannya masih perlu diperhatikan kembali, karena adanya penurunan pada bulan April sampai Juli, yang semula pada bulan April tingkat kehadiran tepat waktu mencapai $83 \%$, tetapi pada bulan Mei sampai Juli mengalami penurunan yaitu $80 \%, 78 \%$ dan $75 \%$. Berdasarkan hasil tersebut, peneliti menduga bahwa hal ini menunjukkan adanya gejala penurunan dimensi conscientiousness yang rendah dari perilaku OCB para karyawannya. Dimana salah satu contoh perilaku dimensi conscientiousness yaitu berdisiplin waktu dalam hal kehadiran.

Selain itu, perilaku OCB bisa dilihat pula dari jumlah karyawan yang keluar (resign). Berdasarkan data yang diperoleh peneliti, terdapat karyawan yang berhenti bekerja dari PT. Ide Jaya Kreasindo sejak tahun 2010 sampai tahun 2014 sudah mencapai 92 orang, dapat dilihat pada tabel 2. 
Tabel 2. Data Karyawan yang Keluar dari PT. Ide Jaya Kreasindo

\begin{tabular}{lcccccc}
\hline & $\mathbf{2 0 1 0}$ & $\mathbf{2 0 1 1}$ & $\mathbf{2 0 1 2}$ & $\mathbf{2 0 1 3}$ & $\mathbf{2 0 1 4}$ & $\begin{array}{c}\text { Total Keseluruhan (2010 } \\
\text { s.d. Agustus 2014) }\end{array}$ \\
\hline Karyawan tetap & 4 & 3 & 5 & 5 & 7 & 24 \\
\hline Karyawan Kontrak & 12 & 11 & 15 & 14 & 16 & 68 \\
\hline Total Per Tahun & $\mathbf{1 6}$ & $\mathbf{1 4}$ & $\mathbf{2 0}$ & $\mathbf{1 9}$ & $\mathbf{2 3}$ & $\mathbf{9 2}$ \\
\hline Sumber: HR Division PT Ide Jaya Kreasindo (2014) & & \\
Pada tabel 2 dijelaskan bahwa intensitas karyawan yang keluar (resign) pada \\
T. Ide Jaya kreasindo terbilang cukup tinggi, dan itu menunjukkan hal yang \\
rbanding terbalik dengan salah satu dimensi OCB yaitu dimensi sportsmanship, \\
dimensi ini menunjukkan suatu kerelaan untuk bertahan dalam suatu \\
endapan dari Triyanto (2009) yang mengatakan bahwa kepuasan kerja dapat \\
dalah rendahnya prestasi kerja, kurang disiplin, rendahnya hasil yang diperoleh
\end{tabular}

Salah satu faktor eksternal yang mempengaruhi pembentukan OCB adalah gaya kepemimpinan, karena menurut Angelina dan Subudi (2014), seorang pemimpin diharapkan dapat memotivasi dan menciptakan kondisi sosial yang menguntungkan bagi setiap karyawan karena dapat meningkatkan kepuasan kerjanya. Ketika gaya kepemimpinan di organisasi mampu menyentuh sisi psikologis karyawan dan mampu menumbuhkan sikap yang positif, maka akan mendorong karyawan lebih loyal demi tujuan organisasi sehingga karyawan terdorong untuk bisa bekerja lebih baik dan tidak hanya terpaku pada job description karyawan. Oleh karena itu, gaya kepemimpinan dapat mempengaruhi tingkah laku karyawan terhadap organisasi itu sendiri, sehingga gaya kepemimpinan dapat menjadi salah satu faktor pembentukan OCB.

\section{Rumusan Masalah}

a. Bagaimana gambaran dari Kepuasan Kerja, Gaya Kepemimpinan dan Organizational Citizenship Behavior pada PT Ide Jaya Kreasindo ? 
b. Apakah Kepuasan Kerja berpengaruh terhadap Organizational Citizenship Behavior pada PT Ide Jaya Kreasindo ?

c. Apakah Gaya Kepemimpinan berpengaruh terhadap Organizational Citizenship Behavior pada PT Ide Jaya Kreasindo ?

d. Apakah Kepuasan Kerja dan Gaya Kepemimpinan secara bersama-sama berpengaruh terhadap Organizational Citizenship Behavior pada PT Ide Jaya Kreasindo ?

\section{Tujuan Penelitian}

1. Untuk mengetahui gambaran Kepuasan Kerja, Gaya Kepemimpinan dan Organizational Citizenship Behavior pada PT Ide Jaya Kreasindo.

2. Menguji secara empiris pengaruh kepuasan kerja terhadap Organizational Citizenship Behavior pada PT Ide Jaya Kreasindo.

3. Menguji secara empiris pengaruh gaya kepemimpinan terhadap Organizational Citizenship Behavior pada PT Ide Jaya Kreasindo.

4. Menguji secara empiris pengaruh kepuasan kerja dan gaya kepemimpinan secara bersama - sama terhadap Organizational Citizenship Behavior pada PT Ide Jaya Kreasindo.

\section{KAJIAN TEORETIK}

\section{Organizational Citizenship Behavior}

Menurut Organ (2006) Organizational Citizenship Behavior adalah perilaku individu bebas, tidak berkaitan secara langsung atau eksplisit dengan sistem reward formal organisasi dan bisa meningkatkan fungsi efektif organisasi.

Robbins dan Judge (2009:64) berpendapat bahwa "Organizational Citizenship Behavior adalah suatu perilaku yang bukan merupakan bagian dari persyaratan kerja formal namun dapat meningkatkan keefektifan fungsi suatu organisasi”. Hal ini senada dengan pendapat dari Garay (dalam Minadaniati, 2012) yang menjelaskan bahwa "OCB merupakan perilaku sukarela dari seorang 
pekerja untuk mau melakukan tugas atau pekerjaan di luar tanggung jawab atau kewajibannya demi kemajuan atau keuntungan organisasinya".

Berdasarkan definisi yang telah disebutkan oleh para ahli diatas maka peneliti mengambil kesimpulan bahwa OCB adalah merupakan perilaku sosial yang bersifat tulus dan sukarela tanpa harus diperintah oleh perusahaan dari seorang karyawan diluar kerja formal yang sangat menguntungkan bagi perusahaan. Serta tidak berhubungan langsung dengan sistem reward dan tidak memasukkan unsur pemaksaan untuk melakukan suatu pekerjaan ekstra di luar kewajiban atau tanggung jawabnya demi kemajuan organisasi, yang berarti perilaku tersebut merupakan inisiatif dari tiap individu dan tidak termasuk dalam deskripsi kerja.

\section{Kepuasan Kerja}

Menurut Robbins dan Judge (2007:73), kepuasan kerja adalah suatu perasaan positif tentang pekerjaan seseorang yang merupakan hasil dari sebuah evaluasi karakteristiknya. Seseorang dengan tingkat kepuasan kerja yang tinggi memiliki perasaan-perasaan positif tentang pekerjaan tersebut, sementara seseorang yang tidak puas memiliki perasaan yang negatif tentang pekerjaannya tersebut. Sementara itu, menurut Hughes (2009:372) mendefinisikan kepuasan kerja yaitu kepuasan kerja bukan menunjukkan seberapa keras seseorang bekerja atau seberapa baik seseorang bekerja, melainkan lebih kepada seberapa besar seseorang menyukai beberapa jenis pekerjaan yang spesifik/aktivitas kerja. Kepuasan kerja berhubungan dengan sikap atau perasaan tentang pekerjaan itu sendiri, bayaran, promosi atau kesempatan pendidikan, pengawasan, teman kerja, kapasitas kerja dan lain-lain.

Sedangkan Locke (dalam Fidiyanti, 2009) mendefinisikan kepuasan kerja sebagai emosi positif atau perasaan senang karyawan, sebagai hasil dari pengawasan seorang atasan kepada bawahan terhadap faktor pekerjaan atau pengalaman-pengalaman kerjanya.

Berdasarkan definisi yang telah disebutkan oleh para ahli diatas maka peneliti mengambil kesimpulan bahwa kepuasan kerja adalah sikap positif dan 
rasa senang karyawan terhadap pekerjaannya, dimana seorang karyawan akan merasa puas jika apa yang mereka butuhkan telah tercapai yang merupakan hasil dari evaluasi karakteristiknya seperti, gaji, promosi, pekerjaan itu sendiri, pengawasan dan rekan kerja. Semakin tinggi tingkat kepuasan kerja dari karyawan, maka semakin besar peluang karyawan tersebut untuk memberikan kontribusi maksimal bagi perusahaan atau organisasi.

\section{Gaya Kepemimpinan}

Menurut Stodgill (dalam Sutarto 2012:12) gaya kepemimpinan adalah proses mempengaruhi kegiatan-kegiatan sekelompok orang yang terorganisasi dalam usaha mereka menetapkan dan mencapai tujuan.

Menurut Pfiffner dan Presthus (dalam Sutarto 2012: 15) gaya kepemimpinan adalah seni mengkoordinasi dan memotivasi individu-individu serta kelompokkelompok untuk mencapai tujuan yang diinginkan. Sementara itu Hersey dan Blanchard (dalam Sutarto 2012:22) berpendapat bahwa gaya kepemimpinan adalah proses mempengaruhi kegiatan individu atau kelompok dalam usaha untuk mencapai tujuan dalam situasi tertentu.

Berdasarkan penjelasan diatas, gaya kepemimpinan adalah proses mempengaruhi, mengkoordinasi dan memotivasi individu atau kelompok dalam usaha untuk menetapkan dan mencapai tujuan tertentu yang diinginkan. 


\section{Hipotesis Penelitian}

H1 : Kepuasan Kerja berpengaruh secara signifikan terhadap OCB.

H2 : Gaya Kepemimpinan berpengaruh secara signifikan terhadap OCB.

H3 : Kepuasan Kerja dan Gaya Kepemimpinan secara bersama-sama berpengaruh signifikan terhadap OCB.

\section{H1}

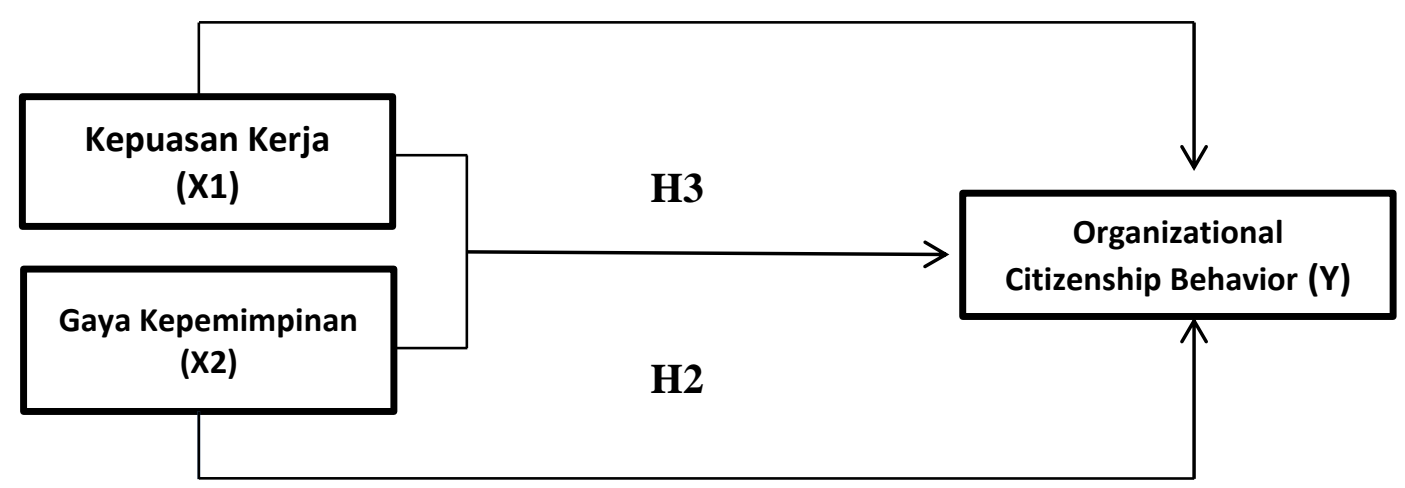

Gambar 1. Model Penelitian

Sumber:Data Diolah Peneliti,2014

\section{METODE PENELITIAN}

Penelitian menggunakan metode penelitian deskriptif dan korelasional. Penelitian deskriptif merupakan penelitian terhadap masalah-masalah berupa fakta-fakta saat ini dari suatu populasi. Menurut Indriantoro \& Supomo (2002:33) "tujuan penelitian deskriptif adalah untuk menguji hipotesis atau menjawab pertanyaan yang berkaitan dengan opini (individu, kelompok atau organisasional), kejadian atau prosedur. Sedangkan penelitian korelasional berguna untuk menentukan ada atau tidaknya korelasi antar variabel atau membuat prediksi berdasarkan korelasi antar variabel.

\section{Metode Penentuan Populasi dan Sampel}

Dalam menentukan sampel, peneliti menggunakan rumus Slovin (Umar, 2008: 65) sebagai berikut:

$$
n=\frac{N}{1+\mathrm{Ne}^{2}}
$$




$$
\mathrm{n}=\frac{95}{1+95(0,05)^{2}}=76,77(77)
$$

Keterangan:

$\mathbf{n}=$ Ukuran sampel

$\mathbf{N}=$ Ukuran Populasi

e $\quad=5 \%$ kelonggaran ketidaktelitian karena kesalahan pengambilan sampel yang dapat ditoleransi.

Berdasarkan perhitungan menggunakan rumus Slovin tersebut, maka ukuran besarnya sampel yang digunakan dalam penelitian ini sebanyak 76,77 yang dibulatkan menjadi 77 responden.

\section{Metode Analisis}

Tujuan metode analisis data adalah untuk menginterprestasikan dan menarik kesimpulan dari sejumlah data yang terkumpul. Penelitian ini menggunakan perangkat lunak SPSS versi 16.0 untuk mengolah dan menganalisis data hasil penelitian. Beberapa pengujian dilakukan untuk penelitian ini diantaranya adalah sebagai berikut :

1. Uji instrumen yang terdiri dari uji validitas dan uji realibilitas.

2. Uji asumsi klasik yang terdiri dari uji normalitas, uji linearitas, uji multikolinearitas dan uji heterokedastisitas.

3. Analisis linear berganda yang terdiri dari uji t, uji $\mathrm{F}$ dan koefisien determinasi.

\section{HASIL DAN PEMBAHASAN}

\section{Hasil Uji Instrumen}

Peneliti melakukan uji validitas kepada 30 responden untuk mengukur ketepatan kuesioner sebagai instrumen pengukuran. Instrumen dinyatakan valid apabila nilai $r$-hitung yang diperoleh lebih tinggi dibandingkan nilai $r$ tabel pada signifikansi 0,05 sebesar 0,361. Hasil uji validitas pada Tabel 3 menunjukkan, dari 37 item pertanyaan yang diajukan,keseluruhan butir pertanyaan dinyatakan valid. 
Jurnal Riset Manajemen Sains Indonesia (JRMSI) | Vol 6, No. 2, 2015

Tabel 3. Hasil Uji Validitas Instrumen

\begin{tabular}{lccc}
\hline Variabel & $\begin{array}{c}\text { Jumlah item } \\
\text { sebelum diuji }\end{array}$ & $\begin{array}{c}\text { Jumlah item } \\
\text { tidak valid }\end{array}$ & $\begin{array}{c}\text { Jumlah item } \\
\text { Valid }\end{array}$ \\
\hline Kepuasan Kerja (X1) & 13 & 0 & 13 \\
\hline Gaya Kepemimpinan (X2) & 12 & 0 & 12 \\
\hline OCB (Y) & 12 & 0 & 12
\end{tabular}

Untuk uji reliabilitas, jika koefisien Cronbach's Alpha yang diperoleh lebih besar dari 0,6, maka dapat dikatakan tingkat reliabilitasnya dapat diterima. Dari hasil uji reliabilitas pada Tabel 3, ketiga variabel (kepuasan kerja, gaya kepemimpinan dan OCB) dinyatakan reliable atau dapat diandalkan karena nilai Cronbach's Alpha > 0,6.

Tabel 4. Hasil Uji Reliabilitas Instrumen

\begin{tabular}{ccc}
\hline Variabel & Cronbach's Alpha & Keterangan \\
\hline Kepuasan Kerja (X1) & 0,886 & Reliabel \\
\hline Gaya Kepemimpinan (X2) & 0,895 & Reliabel \\
\hline OCB (Y) & 0,854 & Reliabel \\
\hline Sumber:Data Diolah Peneliti,2015 & &
\end{tabular}

\section{Analisis Deskriptif}

Tabel 5. Nilai Analisis Deskriptif

\begin{tabular}{cccc}
\hline & $\begin{array}{c}\text { Kepuasan } \\
\text { kerja }\end{array}$ & $\begin{array}{c}\text { Gaya } \\
\text { Kepemimpinan }\end{array}$ & OCB \\
\hline $\begin{array}{c}\text { Sangat Tidak } \\
\text { Setuju }\end{array}$ & $1,45 \%$ & $1,06 \%$ & $1,30 \%$ \\
\hline Tidak Setuju & $15,58 \%$ & $16,26 \%$ & $16,43 \%$ \\
\hline Netral & $20,37 \%$ & $15,42 \%$ & $15,45 \%$ \\
\hline Setuju & $41,56 \%$ & $39,45 \%$ & $34,55 \%$ \\
\hline Sangat Setuju & $21,30 \%$ & $27,81 \%$ & $32,27 \%$ \\
\hline Sumber: Data diolah oleh peneliti menggunakan Ms.Excel 2010
\end{tabular}

Pada Tabel 4 dapat dilihat persentase jawaban yang diberikan oleh para responden yang menggambarkan setiap variabel. Pada variabel kepuasan kerja, dapat dilihat bahwa jawaban yang diberikan responden didominasi dengan jawaban Setuju yaitu sebesar 41,56\%. Ini menunjukkan bahwa sebagian besar responden telah merasakan kepuasan kerja, akan tetapi pada dimensi pembayaran karyawan merasa bahwa gaji dan tunjangan yang diberikan perusahaan belum cukup untuk memenuhi kebutuhan hidup. Pada variabel gaya kepemimpinan, hasil persentase terbesar berasal dari jawaban Setuju yaitu sebesar 39,45\% yang 
menandakan bahwa gaya kepemimpinan yang diterapkan sudah cukup baik. Selanjutnya, pada variabel OCB hasil persentase terbesar berasal dari jawaban Setuju yaitu $34,55 \%$. Hal ini juga menandakan bahwa responden kurang memiliki perilaku OCB, karena pada beberapa aspek diketahui bahwa responden mudah mengeluh menghadapi situasi yang sulit, penggunaan fasilitas di luar kepentingan kerja, kurang berdisiplin dengan waktu dan tidak bersedia lembur jika tidak diberikan insentif oleh perusahaan.

\section{UJI ASUMSI DASAR}

\section{Uji Normalitas}

Uji normalitas digunakan untuk mengetahui apakah populasi data berdistribusi normal atau tidak. Dalam penelitian ini akan digunakan uji One Sample Kolmogorov-Smirnov dengan menggunakan taraf signifikansi 0,05.

Tabel 6. Hasil Uji Normalitas

\begin{tabular}{|c|c|c|c|}
\hline \multicolumn{4}{|c|}{ Tests of Normality } \\
\hline & \multicolumn{3}{|c|}{ Kolmogorov-Smirnov $^{\mathrm{a}}$} \\
\hline & Statistic & Df & Sig. \\
\hline Kepuasan Kerja (X1) & .087 & 77 & $.200^{*}$ \\
\hline Gaya Kepemimpinan (X2) & .096 & 77 & .076 \\
\hline OCB (Y) & .092 & 77 & .170 \\
\hline
\end{tabular}

Hasil uji normalitas pada tabel 4.6 menunjukkan bahwa nilai signifikasi untuk variabel Kepuasan kerja sebesar 0.200, Gaya kepemimpinan sebesar 0.076, dan OCB sebesar 0.170. Jadi, variabel kepuasan kerja, gaya kepemimpinan dan OCB berdistribusi normal. Hal tersebut karena ketiga variabel tersebut memiliki nilai signifikansi lebih dari $\alpha=0.05$

\section{Uji Linearitas}

Uji linearitas bertujuan untuk mengetahui apakah dua variabel mempunyai hubungan yang linear atau tidak secara signifikan. Dua variabel 
dikatakan mempunyai hubungan yang linear bila signifikansi (linearity) kurang dari 0,05, Duwi Priyatno (2010:73).

\begin{tabular}{cc}
\multicolumn{2}{c}{ Tabel 7. Hasil Uji Linearitas } \\
\hline Variabel & Nilai Signifikansi \\
\hline Kepuasan Kerja* OCB & 0,000 \\
\hline Gaya Kepemimpinan * OCB & 0,000 \\
\hline
\end{tabular}

Sumber: Data diolah oleh peneliti menggunakan SPSS 16.0 (2015)

Dari Tabel 6, diketahui bahwa masing-masing variabel $\mathrm{X}$ memiliki nilai signifikansi sebesar 0,000. Jadi variabel kepuasan kerja (X1) dan gaya kepemimpinan (X2) dapat dikatakan terdapat hubungan yang linier terhadap OCB (Y) karena nilai Nilai signifikansi $<0,05$.

\section{UJI ASUMSI KLASIK}

\section{Uji Multikolinearitas}

Uji Multikolinearitas digunakan untuk mengetahui ada atau tidaknya penyimpangan asumsi klasik multikolinearitas, yaitu adanya hubungan linear antar variabel independen dalam model regresi. Multikoliniearitas dapat diketahui dengan melihat nilai Variance Inflation Factor (VIF) pada model regresi. Jika besar VIF $<5$ maka mencerminkan tidak ada multikolinieritas.

Tabel 8.Tabel Hasil Uji Multikolinearitas

\begin{tabular}{|c|c|c|c|}
\hline \multicolumn{4}{|c|}{ Coefficients $^{\mathrm{a}}$} \\
\hline \multirow[b]{2}{*}{ Model } & & \multicolumn{2}{|c|}{ Collinearity Statistics } \\
\hline & & Tolerance & VIF \\
\hline \multirow[t]{3}{*}{1} & (Constant) & & \\
\hline & Kepuasan Kerja (X1) & .776 & 1.289 \\
\hline & Gaya Kepemimpinan (X2) & .776 & 1.289 \\
\hline
\end{tabular}

a. Dependent Variable: OCB

Sumber: Data diolah oleh peneliti menggunakan SPSS 16.0 (2015)

Berdasarkan hasil multikolinearitas pada tabel 7, diketahui nilai Variance Inflation Factor (VIF) untuk kedua variabel masing-masing sebesar 1,289. Jadi, dapat disimpulkan bahwa tidak adanya multikolinearitas dalam model regresi yang digunakan, hal ini karena nilai VIF sebesar $1,289<5$. 


\section{Uji Heteroskedastisitas}

Digunakan untuk mengetahui ada atau tidaknya penyimpangan asumsi klasik heteroskedastisitas, yaitu adanya ketidaksamaan varian dari residual untuk semua pengamatan pada model regresi.

Tabel 9.Tabel Hasil Uji Heterokedastisitas

\begin{tabular}{cc}
\hline Variabel & Unstandardized Residual \\
\hline Kepuasan Kerja & .536 \\
\hline Gaya Kepemimpinan & .917 \\
\hline **. Correlation is significant at the 0.01 level (2-tailed). \\
Sumber:Data Diolah oleh peneliti menggunakan SPSS 16.0 (2015)
\end{tabular}

Tabel 8 menjelaskan bahwa nilai signifikansi pada kolom Unstandardized Residual pada produk variabel kepuasan kerja $\left(\mathrm{X}_{1}\right)$ menunjukkan nilai 0,536 dan variabel gaya kepemimpinan $\left(\mathrm{X}_{2}\right)$ sebesar 0,917 dimana nilai tersebut melebihi 0,05 . Hal ini berarti menunjukkan bahwa kedua variabel tersebut tidak terdapat gejala heterokedastisitas.

\section{ANALISIS REGRESI}

\section{Uji t}

Pada Tabel 10, penelitian ini didapat $\mathrm{t}$ hitung untuk sikap sebesar 8,153.

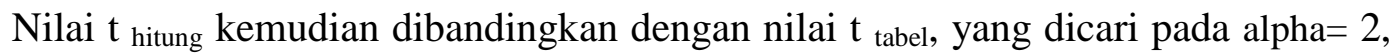
5\% (uji 2 sisi) dengan derajat kebebasan (df) n-k-1 atau 77-2-1, dimana $n$ adalah jumlah sampel dan $\mathrm{k}$ adalah jumlah variabel bebas. Nilai signifikansi 0,05 dan nilai $\mathrm{t}_{\text {tabel }}$ dari 77 responden adalah 1 ,666. Karena nilai $\mathrm{t}$ hitung $(8,153)>\mathrm{t}$ tabel $(1,666)$, maka artinya ada pengaruh variabel kepuasan kerja terhadap variabel OCB.

Tabel 10. Hasil Uji t Kepuasan Kerja dan OCB

\begin{tabular}{|c|c|c|c|c|c|c|}
\hline \multicolumn{7}{|c|}{ Coefficients $^{\mathrm{a}}$} \\
\hline & & Unstandardized & Coefficients & $\begin{array}{l}\text { Standardized } \\
\text { Coefficients }\end{array}$ & & \\
\hline \multicolumn{2}{|c|}{ Model } & B & Std. Error & Beta & $\mathrm{T}$ & Sig. \\
\hline \multirow[t]{2}{*}{1} & (Constant) & 10.093 & 4.212 & & 2.396 & .019 \\
\hline & Kep.Kerja & .739 & .091 & .685 & 8.153 & .000 \\
\hline
\end{tabular}

a. Dependent Variable: OCB 
Berdasarkan pada Tabel 11, nilai $t_{\text {hitung }}$ untuk variabel gaya kepemimpinan adalah 5,399. Karena nilai $t_{\text {hitung }}(5,399)>t_{\text {tabel }}(1,666)$, maka artinya ada pengaruh variabel gaya kepemimpinan terhadap variabel OCB.

Tabel 11.Tabel Uji T Gaya Kepemimpinan dan OCB

\begin{tabular}{|c|c|c|c|c|c|c|}
\hline \multicolumn{7}{|c|}{ Coefficients $^{\mathrm{a}}$} \\
\hline & & Unstandardized & Coefficients & $\begin{array}{l}\text { Standardized } \\
\text { Coefficients }\end{array}$ & & \\
\hline \multicolumn{2}{|c|}{ Model } & $\mathrm{B}$ & Std. Error & Beta & $\mathrm{t}$ & Sig. \\
\hline \multirow[t]{2}{*}{1} & (Constant) & 15.881 & 5.282 & & 3.007 & .004 \\
\hline & G.Kepemimpinan & .640 & .119 & .529 & 5.399 & .000 \\
\hline
\end{tabular}

a. Dependent Variable: OCB

Sumber:Data Diolah oleh peneliti menggunakan SPSS 16.0 (2015)

\section{Uji F}

Tabel 12.Tabel Hasil Uji F Variabel Kepuasan Kerja dan Gaya Kepemimpinan terhadap OCB

\begin{tabular}{|c|c|c|c|c|c|c|}
\hline \multicolumn{7}{|c|}{ ANOVA $^{\mathrm{b}}$} \\
\hline \multicolumn{2}{|c|}{ Model } & \multirow{2}{*}{$\begin{array}{r}\text { Sum of Squares } \\
812.890\end{array}$} & \multirow{2}{*}{$\frac{\mathrm{df}}{2}$} & \multirow{2}{*}{$\begin{array}{r}\text { Mean Square } \\
406.445\end{array}$} & \multirow{2}{*}{$\begin{array}{l}F \\
40.686\end{array}$} & \multirow{2}{*}{$\begin{array}{r}\text { Sig. } \\
.000^{\mathrm{a}}\end{array}$} \\
\hline 1 & Regression & & & & & \\
\hline & Residual & 739.240 & 74 & 9.990 & & \\
\hline & Total & 1552.130 & 76 & & & \\
\hline
\end{tabular}

Berdasarkan pada Tabel 12, nilai $F_{\text {hitung }}$ adalah 40,686 dengan df pembilang=2 dan df penyebut=74 maka diperoleh $F$ tabel adalah 3,12 (uji 2 sisi), maka nilai $F$ hitung $(40,686)>F_{\text {tabel }}(3,12)$. Nilai signifikansi yaitu 0,000 yang artinya lebih kecil dari nilai signifikansi 0.05 maka Ho ditolak. Artinya, variabel kepuasan kerja dan gaya kepemimpinan berpengaruh terhadap variabel dependen OCB. 


\section{Analisis Determinasi}

Tabel 12. Hasil Analisis Determinasi Antara Variabel Kepusan Kerja dan Gaya

\section{Kepemimpinan Terhadap OCB}

\begin{tabular}{|c|c|c|c|c|}
\hline \multicolumn{5}{|c|}{ Model Summary } \\
\hline Model & $\mathrm{R}$ & R Square & Adjusted R Square & $\begin{array}{l}\text { Std. Error of the } \\
\text { Estimate }\end{array}$ \\
\hline 1 & $.724^{\mathrm{a}}$ & .524 & .511 & 3.161 \\
\hline \multicolumn{5}{|c|}{$\begin{array}{l}\text { a. Predictors: (Constant), G.Kepemimpinan, Kep.Kerja } \\
\text { b. Dependent Varaviable: OCB }\end{array}$} \\
\hline Sumber & liolah olel & peneliti meng & gunakan SPSS 16.0 & 2015) \\
\hline
\end{tabular}

Berdasarkan tabel 12, nilai $\mathrm{R}^{2}$ yang tercantum sebesar 0,524. Dengan demikian, variabel kepuasan kerja dan gaya kepemimpinan secara simultan memiliki persentase sumbangan pengaruh terhadap variabel OCB sebesar $52.4 \%$. Sisanya, $47.6 \%$ dipengaruhi oleh variabel lainnya yang tidak terlibat dalam model persamaan regresi linear berganda tersebut. Sementara itu, nilai adjusted $\mathrm{R}^{2}$ sebesar 0.511 .

\section{KESIMPULAN DAN SARAN}

\section{Kesimpulan}

Berdasarkan hasil penelitian tentang yang telah dilakukan, maka beberapa kesimpulan yang bisa ditarik sebagai berikut:

1. Gambaran kepuasan kerja, gaya kepemimpinan dan OCB pada PT Ide Jaya Kreasindo adalah:

a. Kepuasan kerja karyawan PT Ide Jaya Kreasindo sudah cukup baik. Akan tetapi pada dimensi pembayaran, sebagian besar responden merasa gaji dan tunjangan perusahaan yang diberikan belum memenuhi kebutuhan hidup mereka dan tidak puas bila dibanding gaji yang diberikan event organizer lainnya.

b. Gaya kepemimpinan yang diterapkan pada PT Ide Jaya Kreasindo sudah cukup baik. Namun, pada beberapa aspek diketahui bahwa pimpinan tidak selalu memberikan arahan dan penjelasan dalam menyelesaikan pekerjaan secara detail. Pimpinan hanya memberikan arahan pada situasi tertentu saja. 
c. Sementara itu karyawan PT Ide Jaya Kreasindo bisa dikatakan memiliki perilaku OCB yang rendah, karena diketahui pada beberapa aspek karyawan mudah mengeluh dalam situasi yang sulit, penggunaan fasilitas diluar kepentingan kerja, kurang berdisiplin dengan waktu, dan tidak bersedia lembur jika tidak diberikan insentif oleh perusahaan.

2. Terbukti secara empiris kepuasan kerja memiliki pengaruh yang signifikan terhadap Organizational Citizenship Behavior pada karyawan PT Ide Jaya Kreasindo.

3. Terbukti secara empiris gaya kepemimpinan memiliki pengaruh yang signifikan terhadap Organizational Citizenship Behavior pada karyawan PT Ide Jaya Kreasindo.

4. Terbukti secara empiris Kepuasan Kerja dan Gaya Kepemimpinan secara simultan memiliki pengaruh yang signifikan terhadap Organizational Citizenship Behavior pada karyawan PT Ide Jaya Kreasindo.

\section{Saran}

1. Hasil penelitian menunjukkan kepuasan kerja yang berpengaruh terhadap OCB karyawan PT Ide Jaya Kreasindo, hasil ini dapat menjadi bahan acuan bagi pimpinan dengan memperhatikan pembayaran gaji dan tunjangan untuk para karyawan untuk menyesuaikan dengan beban kerja karyawan sehingga diharapkan dapat meningkatkan kepuasan kerja yang nantinya akan mempengaruhi munculnya perilaku OCB.

2. Hasil penelitian menunjukkan gaya kepemimpinan yang berpengaruh terhadap OCB karyawan PT Ide Jaya Kreasindo, hasil ini dapat menjadi acuan bagi pimpinan dengan memberikan penjelasan dan arahan secara detail dan spesifik kepada bawahan dan selalu memberikan motivasi bagi karyawan dalam melakukan aktivitas kerja mereka.

3. Terkait dengan perilaku OCB para pegawai, sebaiknya pihak pimpinan memberikan reward kepada para karyawan yang berprestasi, baik berbentuk finansial maupun non finansial serta menetapkan sanksi ataupun teguran 
kepada para karyawan yang tidak berdisiplin dengan jam masuk kerja sehingga secara efektif dapat meningkatkan kepuasan kerja dan mengubah sikap para karyawan.

\section{Saran bagi penelitian selanjutnya}

1. Penelitian ini dapat dilakukan kembali dengan objek penelitian yang berbeda serta dengan item pernyataan pada kuisioner yang valid dan reliabel.

2. Berdasarkan nilai koefisien determinasi untuk kepuasan kerja dan gaya kepemimpinan, masih terdapat variabel lain yang mempengaruhi OCB yang dapat digunakan dalam penelitian lanjutan.

\section{DAFTAR PUSTAKA}

Fidiyanti, Novi, 2009. "Pengaruh kepemimpinan terhadap perilaku Citezenship, kepuasan kerja dan Komitmen organisasional”. Jurnal Universitas Muhammadiyah Surakarta.

Hughes, Richard L, Robert C. Ginnet, Gordon J. Curphy. 2009, Leadership: Enhancing the Lessons of Experience, $6^{\text {th }}$ edition, Singapore: McGrawHill

Indriantoro, dan Supomo. Metodologi Penelitian Bisnis untuk Akuntansi dan Manajemen. Edisi Pertama. Yogyakarta : BPFE-Yogyakarta, 2002.

Minadaniati, Lussy dan Agung Waspodo. 2012. "Pengaruh Kepuasan kerja dan Iklim Organisasi terhadap OCB karyawan pada PT. Trubus Swadaya”. Jurnal Riset Sains Manajemen Vol. 3, No.1

Organ, D.W., et.al. 2006. Organizational Citizenship Behavior. Its nature, antecendents and Consequences. California: Sage Publications, Inc.

Priyatno, Duwi, 2010. Paham Analisis Statistik Data dengan SPSS. Yogyakarta: Media kom

Ristiani, Rista. 2014. "Pengaruh Gaya Kepemimpinan dan Komitmen Organisasi terhadap OCB Studi pada BAUK UNJ”. Jurnal Manajemen Universitas Negeri Jakarta 
Robbins, Stephen P. dan Timothy A. Judge. 2009. Organizational Behavior, $13^{\text {th }}$ edition, United States: Prentice Hall.

Soegandhi, et al. 2013. "Pengaruh Kepuasan kerja dan Loyalitas kerja terhadap OCB pada karyawan PT.Surya Timur Sakti Jatim”. Jurnal Manajemen. Vol 1, No 1.

Umar, Husein, 2009. Metode Penelitian untuk Skripsi \& Tesis Bisnis. Jakarta: Rajawali pers 